\title{
Performance of Densified Wood Glulam as Building Bio-Material
}

\author{
Reza Hajihassani ${ }^{1}$, Saman Ghahri ${ }^{1}$, Seyedeh Masoomeh Zamani ${ }^{2}$ and Amir Nourbakhsh ${ }^{1, *}$ \\ ${ }^{1}$ Wood and Forest Products Research Division, Research Institute of Forests and Rangelands, Agricultural Research, Education and \\ Extension Organization (AREEO), Tehran, 19395-1113, Iran \\ ${ }^{2}$ Research Institute of Forests and Rangelands, Agricultural Research, Education and Extension Organization (AREEO), Tehran, \\ 19395-1113, Iran
}

*Corresponding Author: Amir Nourbakhsh. Email: Nourbakhsh_amir@yahoo.com

Received: 06 June 2021 Accepted: 05 July 2021

\begin{abstract}
In this research, some practical aspects of densified wood glulam were investigated. For this aim, poplar wood specimens were densified by hygro-thermo-mechanical technique. Glulam specimens were produced by finger joint technique and polyurethane glue was used as resin. Physical and mechanical properties of glulams were investigated according to ASTM D 143-09, ASTM D 905-03 and ISO 8375 standards. Based on obtained results, using this process (steam and pressurize compaction) resulted in improvement of physical and mechanical properties of glulam specimens. Optical microscopic and scanning electron microscopic (SEM) pictures were proved structural changes on wood material during of applied technique. Generally, the increase of wood density and hygrothermal treatment has a positive role on the glulam properties especially its dimensional stability. This technique showed a significant effect on water absorption; the steaming temperature and holding time significantly decreased water absorption but densification process increased this parameter. Also, delamination of specimens was decreased by hygrothermal treatment while densification showed negative effect on delamination. Moreover, modulus of rupture, modulus of elasticity, shear strength and compression strength parallel to grain were decreased by this technique but it is depend to treatment temperature and holding time. Higher temperature and holding time cause to higher decrease in the glulam mechanical strength.
\end{abstract}

\section{KEYWORDS}

Wood; modification; glued laminated timber; physical and mechanical properties

\section{Introduction}

Considering environmental sustainability, using renewable materials like wood timber and other wood products for building construction have major priority than other materials. Glue laminated timber (glulam) is one of the most popular and most used type of engineered wood products in recent years [1]. This product is made from sawn lumber lamina glued together in horizontal layers, using scarf or finger joints to provide the desired length [2]. Sawn lumber laminations bonded together with a resin, so that the grain of all layers runs parallel with the longitudinal direction [3]. One of the disadvantages of massive wood in applications is dimensional restriction. Glulam can be made from small-diameter timber and provide high strength and large spans in architectural designs and other applications. In order to enhance the bearing capacity of structural components, save materials, and reduce cost, a glulam that is theoretically suitable 
for engineering application [4]. Also, Glulam can bring the natural beauty of source wood in wooden construction, and widely used. This is due to its unique properties such as easy production, lightness, high strength and various forms of its application. The other structural application of glulam is in columns, trusses, reinforcing members, bridges deck and etc. Besides, the bonding ability of glulam components provides it for further applications [4-9]. The interest to apply this technology is to reduce product variability and make it less affected by natural growth features like knots. In addition, the glulam technology offers almost unlimited possibilities of shape and design for construction, and is widely used for load bearing structures in houses, pedestrian bridges, warehouses, etc.

However, glulam has some disadvantages and limitations of solid wood such as water absorption, swelling, etc. Therefore, the various methods of modification has been used in recent years such as chemical modification, thermal treatment, enzymatic modification, or a combination of them to improve these materials characteristics and their applications capabilities.

The modification generally targets dimensional stability, i.e., reduce moisture induced movement, and increase durability, i.e., resistance to degradation [10]. One of the modification methods is hydrothermal treatment. The results of studies in different fields of hydrothermal processes showed that wood physical characteristics are improved due to the treatment [11]. In hydrothermal process, formation of the hydronium ions due to water hydrolysis causes hydrolysis of lignocellulosic linkages. In fact, hydronium ions act as an acid and hydrolyze wood polysaccharides. In the presence of ions, reactions of hydrolysis and de-acetylation increased in cell wall [12]. There are no some problems such as harmful components, corrosion, chemical recovery and destruction in this method [13]. The hygrothermal treatment removes the acetyl groups of acetylated hemicelluloses by generating of acetic acid. This acid lead to production of water-soluble mono saccharides (glucose, galactose, mannose, arabinose and xylose) due to hydrolyses of cell wall polysaccharides [14,15]. Moreover, the produced acetic acid is a factor promoting lignin breakdown. Degradation of ß-O-4 linkages in lignin of the softwood during hydrothermal treatment cause decrease wood rigidity [16]. The reconstructed lignin improves bending strength of the treated sample as well as resistance to water adsorption $[17,18]$.

Heat treatments are the other eco-friendly modification methods usually which carried out at a temperature of $160-260^{\circ} \mathrm{C}[19,20]$. Heat treatment of wood at temperature of $140-260^{\circ} \mathrm{C}$ improves dimensional stability of wood [21-23]. Moreover, it causes less moving of moisture in [24], improvement of biological degradation resistance $[25,26]$. However, wood treatment at high temperatures reduces its mechanical resistance such as strength, hardness and stiffness [27]. Reduction of mechanical properties depends on the method of heat treatment, time and temperature of treatment, wood species, initial moisture content of wood and heating atmosphere [28]. In order to solve this problem in thermal and hydrothermal treatments we can use other modification methods including mechanical modification, hydro-thermo-mechanical modification, hygro-thermo-mechanical modification and etc.

Increasing the density of wood enhances most of its mechanical properties. Wood compression is an effective method to increase the density of wood [29]. The compressed wood products can be substitute with high density wood products [30]. Therefore densification of wood is suitable for low-density species such as aspen and poplar hybrid [31]. On the other hand, due to the hydrothermal modification, which occurs in the wood densification processes, the obtained products have a higher mechanical properties [32,33], reduced equilibrium moisture content [34], improved biological strength [35] as well as dimensional stability [36-39].

Thermo-hygro-mechanical treatment is the other modification method in which used heat, steam, and pressure [33,35,39-45]. This technique not only makes wood hydrophobic $[43,46,47]$ and resistant to biological degradation $[48,49]$, but also increases its mechanical strength $[43,50]$; therefore it can be used for low-density species such as poplar [31,43]. 
In the current research work, the applying necessity of hygro-thermo-mechanical treatment in glulam production is due to elimination of disadvantages and limitations of solid wood. Therefore, obtaining optimum conditions in this method can bring superior functional properties of the product. In other words, in hygro-thermo-mechanical technique, not only the proper condition of steaming and heating can provide suitable physical properties, but also densification process resolve some mechanical weaknesses which caused by hygrothermal treatment such as lose weight and strength reduction.

\section{Materials and Methods}

Wood blocks were prepared from poplar wood (Populus deltoides) with dimensions of $50 \times 50 \times 500 \mathrm{~mm}^{3}$. Then, the specimens treated hygrothermally at temperatures of 130,150 , and $170^{\circ} \mathrm{C}$ for holding time of 20 and $40 \mathrm{~min}$. Afterwards, poplar blocks due to the high moisture content were initially air dried and then oven-dried to achieve MC (moisture content) 15 percent. Compression process of wood blocks were immediately carried out by hot press in radial direction with a compression set of $40 \%$ and $60 \%$ and press temperatures of $160^{\circ} \mathrm{C}$ for $20 \mathrm{~min}$ [43]. Tab. 1 shows composition of variable parameters with related code. Polyurethane resin (Mokarrar Co., Iran) was used as adhesive for glulam production.

Table 1: Composition of variable parameters with related code

\begin{tabular}{|c|c|c|c|c|c|c|c|c|c|c|c|c|c|}
\hline \multirow{2}{*}{$\frac{\text { Hygrothermal temp. }\left({ }^{\circ} \mathrm{C}\right)}{\text { Holding time (min.) }}$} & \multicolumn{2}{|c|}{130} & \multicolumn{4}{|c|}{150} & \multicolumn{4}{|c|}{170} & \multirow{2}{*}{\multicolumn{3}{|c|}{$\begin{array}{l}\text { Control } \\
\text { No treat } \\
\end{array}$}} \\
\hline & $20(\mathrm{~A})$ & $40(\mathrm{~B})$ & & (C) & 40 & (D) & 20 & & 40 & (F) & & & \\
\hline Compression set (\%) & 40 & 60 & 40 & 60 & 40 & 60 & 40 & 60 & 40 & 60 & 40 & 60 & No treat \\
\hline Code & A1 A2 & B1 B2 & $\mathrm{C} 1$ & $\mathrm{C} 2$ & D1 & D2 & E1 & E2 & $\mathrm{F} 1$ & $\mathrm{~F} 2$ & $\mathrm{P} 1$ & $\mathrm{P} 2$ & $\mathrm{U}$ \\
\hline
\end{tabular}

The next step (after treatments and climatisation) was to make finger joint on the treated specimens. The specimens were then cut in desired longitudinal dimension to glulam production. 6 blade Groove cuter were used for preparing the finger joints. Polyurethane adhesive with consumption rate of $200 \mathrm{~g} / \mathrm{m}^{2}$ were used to connect prepared blocks. The assembled glulams were placed in cold press with pressure $0.8 \mathrm{~N} / \mathrm{mm}^{2}$ for $8 \mathrm{~h}$ [51]. Fig. 1 shows assembled glulam, cold press and completion of resin curing after press. Finally, the glulams were conditioned at $25 \pm 2{ }^{\circ} \mathrm{C}$ temperature and $65 \pm 5 \%$ relative humidity for 4 weeks. Totally, 75 glulams were made according to variable factors (three levels of steaming temperature, two levels of holding time and two levels of compression set) with 5 replications and also control specimens (control specimens, control specimens with compression set of $40 \%$ and control specimens with compression $60 \%$ ).

The mechanical properties (bending strength, modulus of elasticity, shear strength of glueline and compression strength parallel to grain) of glulams which made from treated and untreated wood specimens were determined according to ASTM D 143-09, ASTM D 905-03 and ISO 8375. Physical properties such as density $\left(5 \times 5 \times 5 \mathrm{~cm}^{3}\right)$, water absorption, radial and tangential swelling, dimensional stability (Anti swelling efficiency) as well as delamination were also determined. The results were statistically analyzed based on a complete randomized design under factorial experiment and the mean values were grouped according to Duncan's multiple range test.

\section{Results and Discussion}

\subsection{Physical Properties}

\subsubsection{Density}

The results showed that wood densification based on the compression sets (C.S.) of $40 \%$ and $60 \%$ significantly increased the glulam density in controls and treated specimens due to increment of wood material in equal volume (Fig. 2). The effect of variable parameters on density in Fig. 2 also indicated 
that the density of hygrothermal treated specimens was a little more than control specimens with the same C.S. which is due to collapse and enhancement of density in equal volume [51].
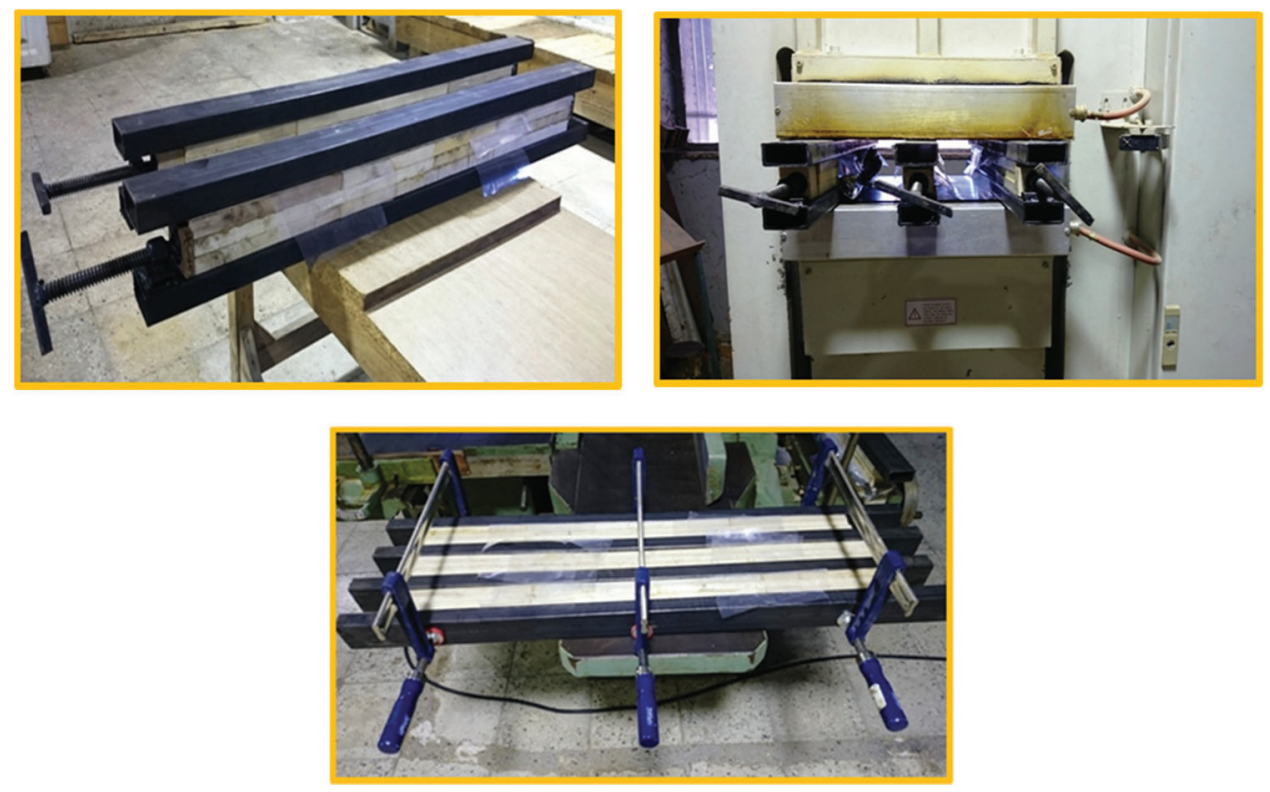

Figure 1: Assembling, cold pressing and completion of resin curing after press

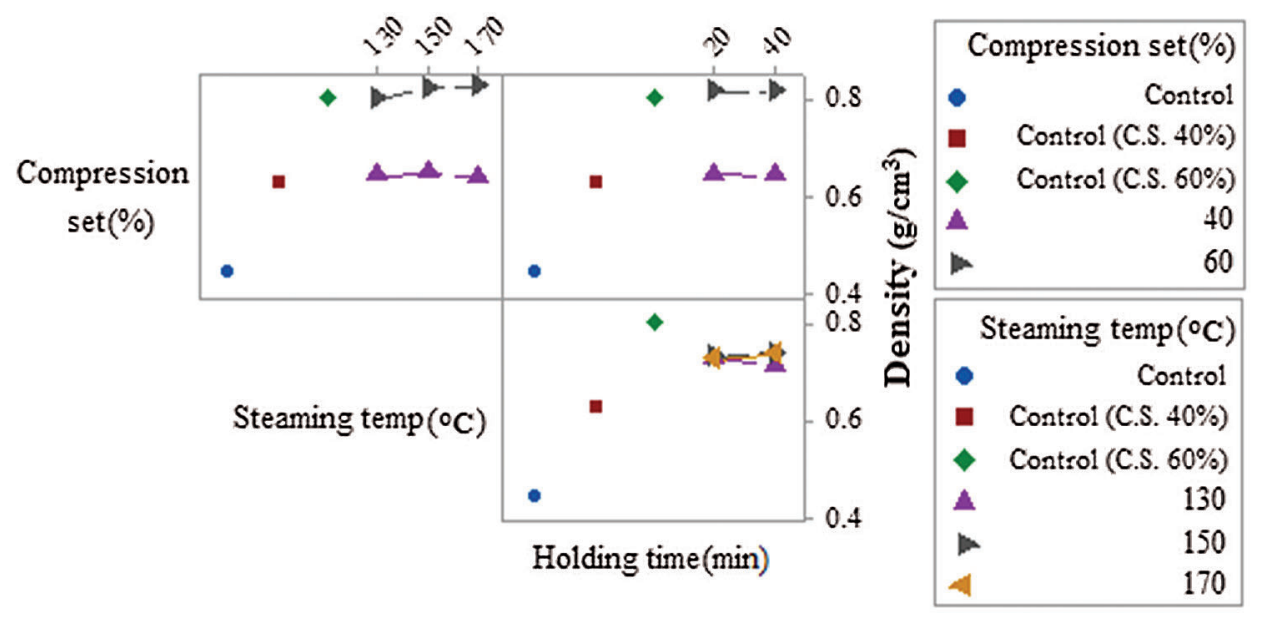

Figure 2: Effect of hygro-thermo-mechanical treatment parameters on density

\subsubsection{Water Absorption}

The results showed that steaming temperature, holding time as well as compression set had significant effect on water absorption after 24,48 and $72 \mathrm{~h}$ soaking in water. Figs. $3 \mathrm{a}$ and $3 \mathrm{~b}$ showed the comparison of steaming temperature effect on water absorption after 24 and $72 \mathrm{~h}$ of soaking in water. The results revealed positive effect of steaming temperature on water absorption properties, so that, the water absorption of treated specimens at steaming temperature of $170^{\circ} \mathrm{C}$ was lower than control specimens. Moreover, this figure revealed that moisture absorption was decreased with increasing of holding time. The elimination of hemicelluloses due to hydrolysis reaction and blocking of hydroxyl groups in cellulose, reduce 
hygroscopic feature and water absorption of wood [43]. In fact, the presence of hemicelluloses-derived acetic acid not only causes hydrolyze the polysaccharides of cell wall, but is also a factor for promoting lignin breakdown. Therefore, elimination of hydroxyl groups and modified lignin improve the resistance of treated wood to water absorption $[15,17,18]$. Moreover, using of waterproof polyurethane adhesive can also be a factor to reduction of water absorption.
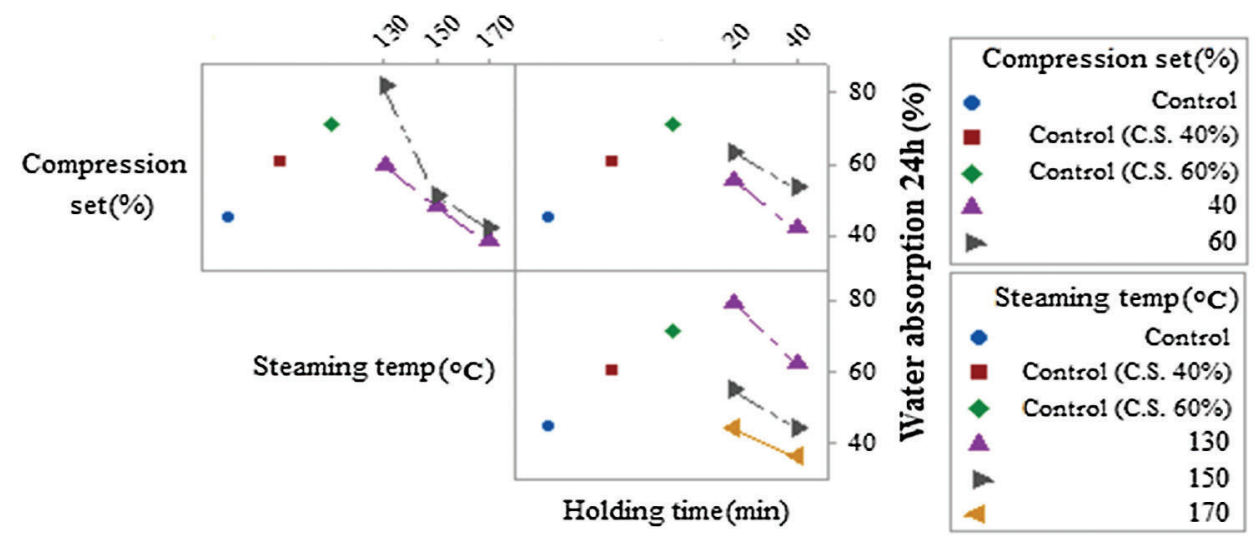

(a)
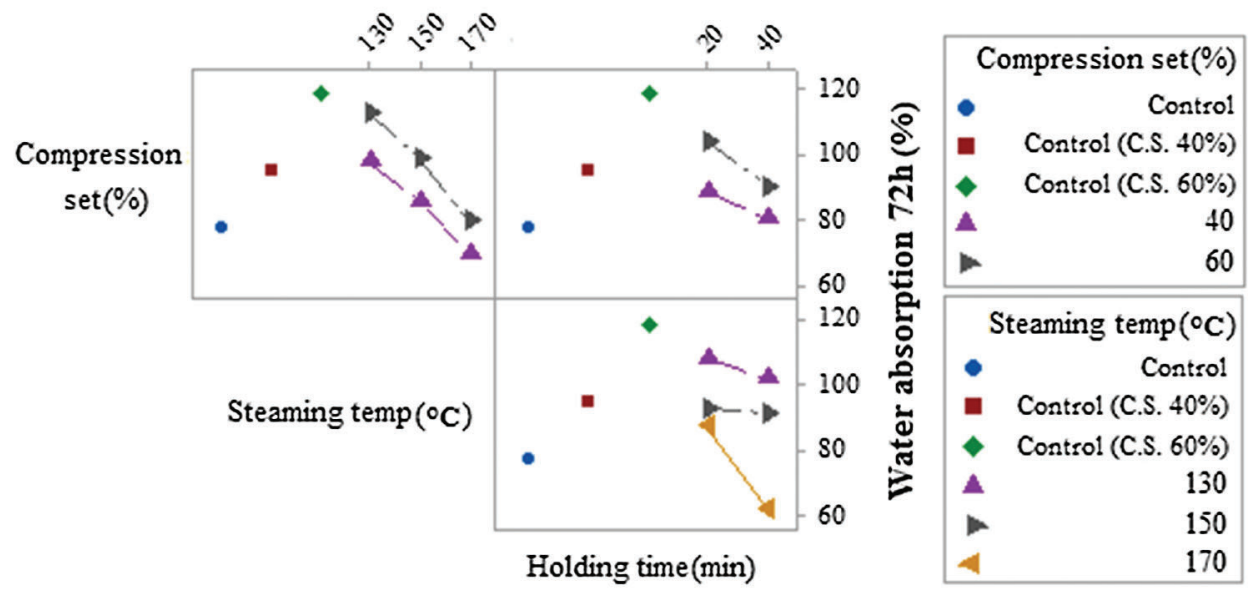

(b)

Figure 3: Effects of hygro-thermo-mechanical treatment parameters on water absorption of glulam after 24 $\mathrm{h}(\mathrm{a})$ and $72 \mathrm{~h}(\mathrm{~b})$ soaking in water

As indicated in Fig. 3, water absorption after 24 and $72 \mathrm{~h}$ of soaking in water had increased with compression set enhancement, due to the greater volume of wood material. Interaction effect of compression set on water absorption in Fig. 3 revealed the positive effect of hygrothermal modification on water absorption of treated specimens in compared with controls. So that, the water absorption of control specimens with compression set of $40 \%$ and $60 \%$ were higher than hygrothermal treated specimens with the same densification. 


\subsubsection{Radial and Tangential Swelling}

The thickness swelling of glulams in radial and tangential direction was determined after 24 and $48 \mathrm{~h}$ of soaking in water. The results revealed that the radial swelling was reduced by increasing of the steaming temperature as well as the holding time after 24 and $48 \mathrm{~h}$ of soaking in water (Fig. 4). So that the least radial swelling, between the compressed specimens, was related to steaming temperature of $170^{\circ} \mathrm{C}$ and holding time of $40 \mathrm{~min}$ (Fig. 4). As previously mentioned, the elimination of hemicelluloses due to hydrolysis reaction and blocking of hydroxyl groups in cellulose caused reduction of hygroscopic feature of wood and radial thickness swelling [43].
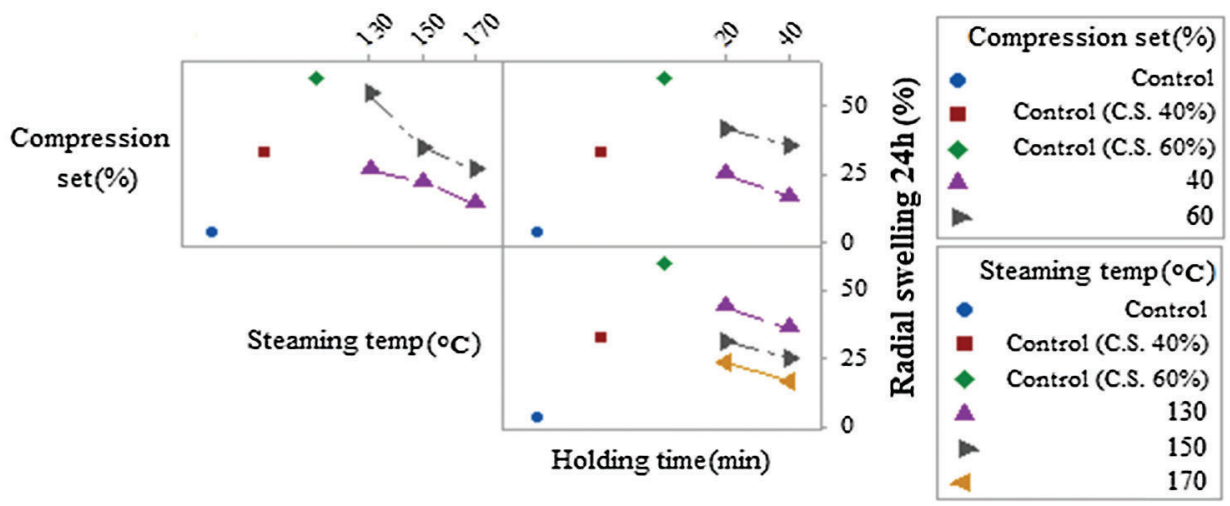

(a)
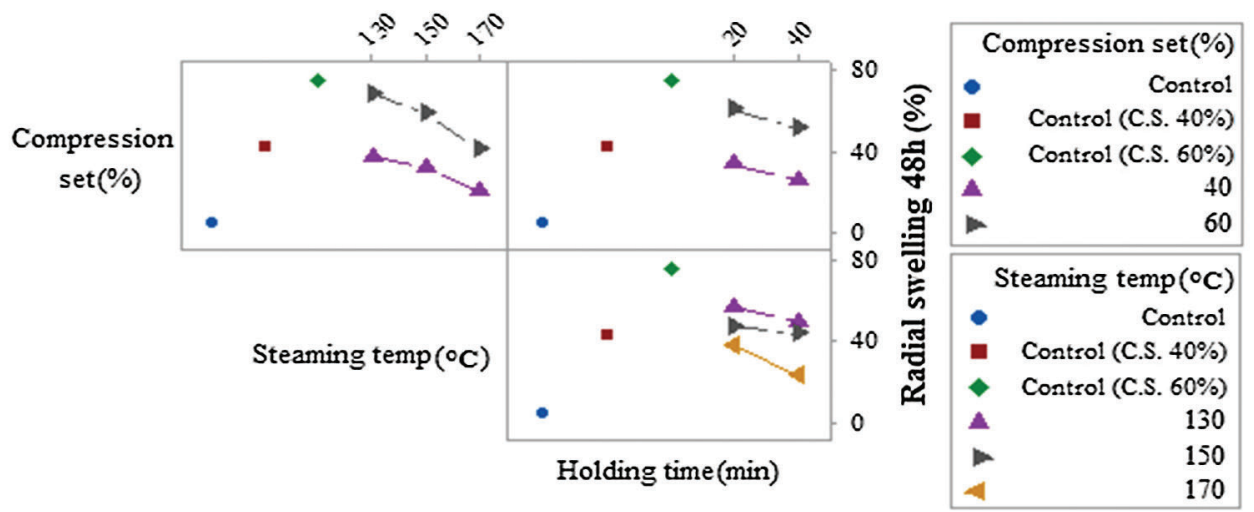

(b)

Figure 4: Effects of hygro-thermo-mechanical treatment parameters on radial swelling of glulam after $24 \mathrm{~h}$ (a) and $48 \mathrm{~h}$ (b) soaking in water

The interaction effect of compression set on radial swelling, as indicated in Fig. 4, revealed that an enhancement of the compression set caused increase of the radial swelling of glulams. But remarkable point was low radial swelling of treated specimens by hygrothermal process compared the control specimens with the same compression set. This appeared significant effect of hygrothermal treatment on reduction of water absorption and swelling.

According to the results, the tangential swelling of specimens after 24 and $48 \mathrm{~h}$ of soaking in water was reduced by increasing of hygro-thermo-mechanical treatment parameters as steaming temperature, holding time and compression set (Figs. 5a and 5b). The increasing of steaming temperature and holding time 
caused the hemicelluloses hydrolysis and elimination or blocking of hydroxyl groups in cellulose and finally were reduced tangential swelling [43]. But edge cutting of compressed wood with compression set of $60 \%$ removed more wood materials in compared with compression set of $40 \%$; therefore, after soaking of specimens in water and radial thickness swelling, their sides become concave and tangential swelling decreased, consequently (Fig. 6).

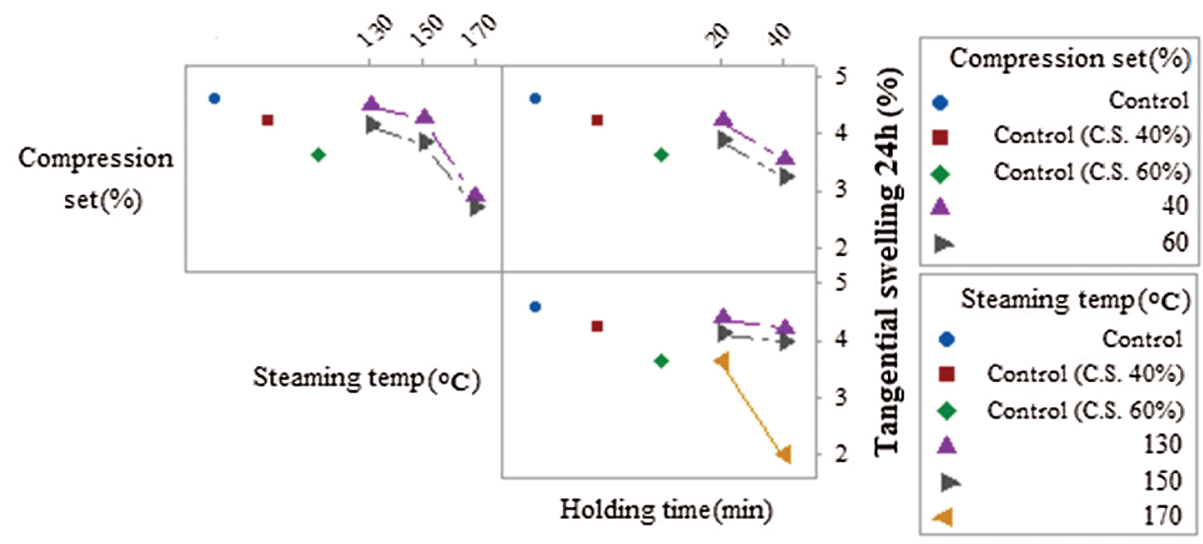

(a)

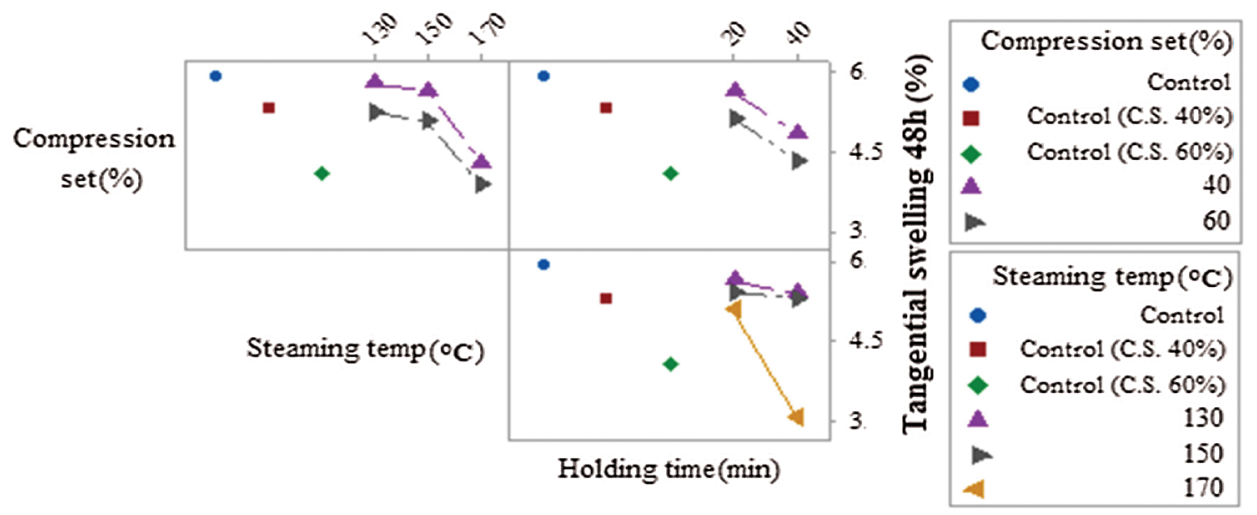

(b)

Figure 5: Effects of hygro-thermo-mechanical treatment parameters on tangential swelling of glulam after $24 \mathrm{~h} \mathrm{(a)}$ and $48 \mathrm{~h}(\mathrm{~b})$ soaking in water

\subsubsection{Dimensional Stability}

The dimensional stability of specimens was determined after 5 stages of soaking-drying ( $24 \mathrm{~h}$ soaking in water and then oven drying). The results showed significant effect of steaming temperature as well as the holding time on dimensional stability. As indicated in the Fig. 7, the dimensional stability of the treated specimens at steaming temperature of 130 and $150^{\circ} \mathrm{C}$ and holding time of $20 \mathrm{~min}$ had no any significant change during the five cycles, which appears positive and lasting effect of hygrothermal treatment on dimensional stability. But when the steaming temperature and holding time were raised to $170^{\circ} \mathrm{C}$ and 40 min, respectively, the dimensional stability decreased with continuing of soaking-drying cycles. Because intensification of hygrothermal treatment condition caused brittleness of the lignin polymer as well as the cleaved cellulose polymer chains [43], as a result, applying mechanical force create small crack and fractures which can increase moisture penetration and also water absorption. 

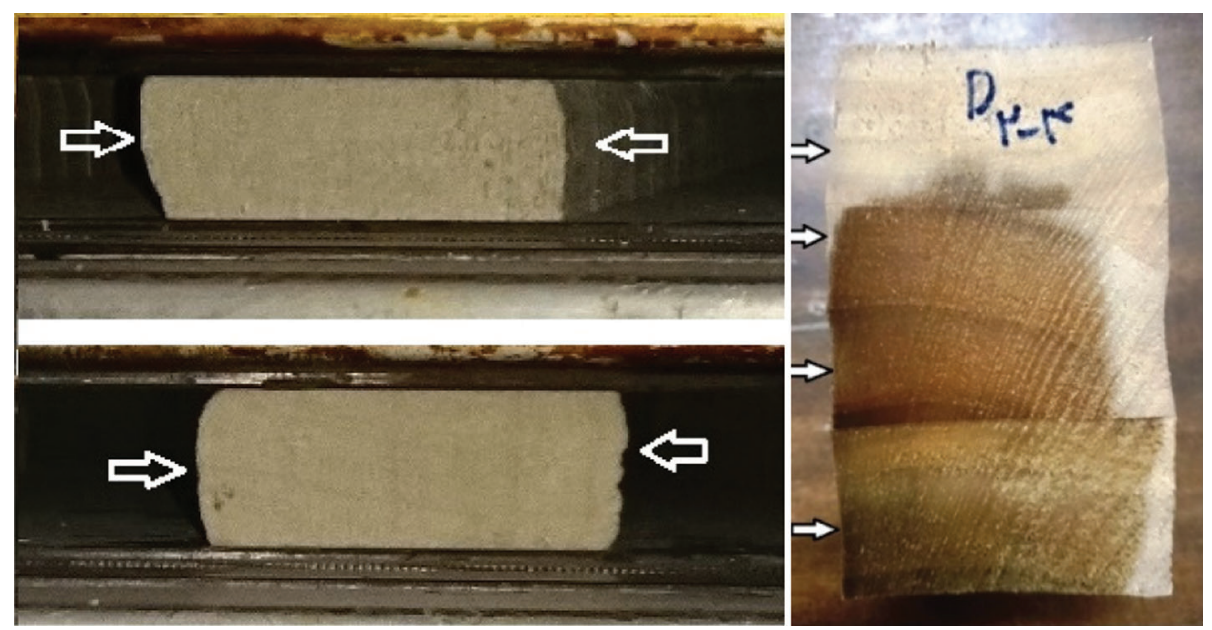

Figure 6: Tangential swelling changes in hygro-thermal treated specimen after soaking in water (left), convex edge of specimen after compression (right)
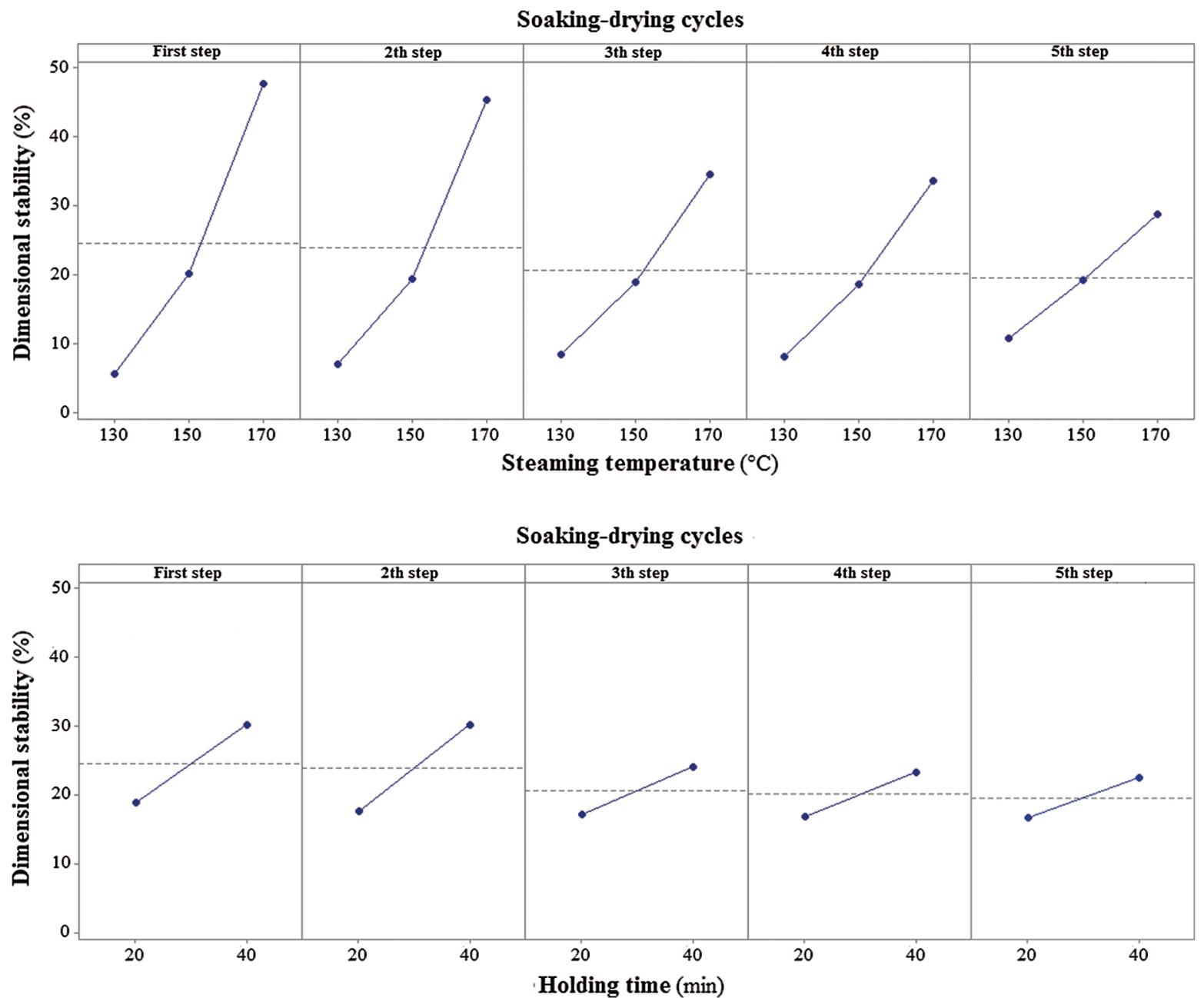

Figure 7: Effect of steaming temperature (up) and holding time (down) on dimensional stability during 5 soaking-drying cycles in hygro-thermo-mechanical treatment parameters 


\subsubsection{Delamination}

The delamination of glulam specimens was determined after two soaking-drying cycles $(24 \mathrm{~h}$ soaking in water and then oven drying). The results revealed positive significant effect of hygro-thermo-mechanical treatment on delamination, so that, the delamination of treated specimens by this process were less than control specimens (Fig. 8). According to the results shown in Fig. 8, the delamination of control specimens had increased by raising of compression set, but it was vice versa about hygrothermal treated specimens; so that, the delamination of hygro-thermo-mechanical treated specimens with compression set of $40 \%$ and $60 \%$ had reduction of $44.8 \%$ and $70.03 \%$ respectively in compared with control specimens with the same compression set. The hygrothermal treatment not only reduces moisture absorption, swelling as well as swelling-derived stress due to the hemicelluloses hydrolysis and elimination or blocking of hydroxyl groups in cellulose, but also caused brittleness of the lignin polymer and cleavage of cellulose polymer chains [43]. On the other hand, compression process increases small cracks, as a result improve adhesive penetration as well as the mechanical junctions. Therefore, all of these factors can reduce the delamination of hygro-thermo-mechanical treated specimens.

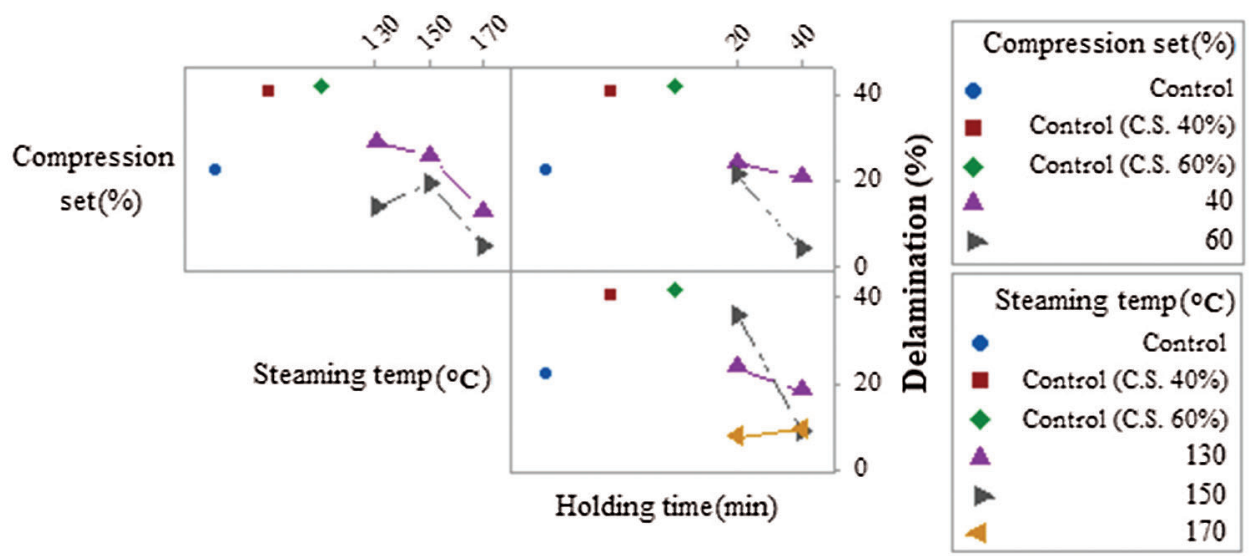

Figure 8: Effects of hygro-thermo-mechanical treatment parameters on delamination of glulam after two soaking-drying cycles

\subsection{Mechanical Properties}

\subsubsection{Modulus of Rupture and Modulus of Elasticity}

The result revealed all parameters of hygro-thermo-mechanical treatment had significant effect on bending modulus of rupture (MOR). According to the results shown in Fig. 9a, the MOR of the control specimens was increased by densification because of density enhancement [32,33]. Also, SEM photos (Fig. 10) clearly showed that how densification occurred during treatment. Increasing the wood compaction causes to increase the MOR in treated wood. But in the hygrothermal treated specimens, increase of the steaming temperature showed different effects on the MOR (Fig. 9a). As shown, the MOR was increased up to temperature $150^{\circ} \mathrm{C}$ and then there was reduction at treatment temperature of $170^{\circ} \mathrm{C}$. There was also reduction of MOR when the holding time was raised up to 40 min (Fig. 9a). Moreover, Similar with the control specimens, increase of the densification intensity had positive effect on the MOR of the hygrothermal treated specimens. The MOR of hygrothermal treated specimens with C.S. of $40 \%$ was more than control specimens with the same densification (Fig. 9a). There was also a little difference between MOR of control specimens with C.S. of $60 \%$ and hygrothermal treated specimens with the same densification (Fig. 9a). This appears because of the significant effect of hygrothermal modification on MOR. 

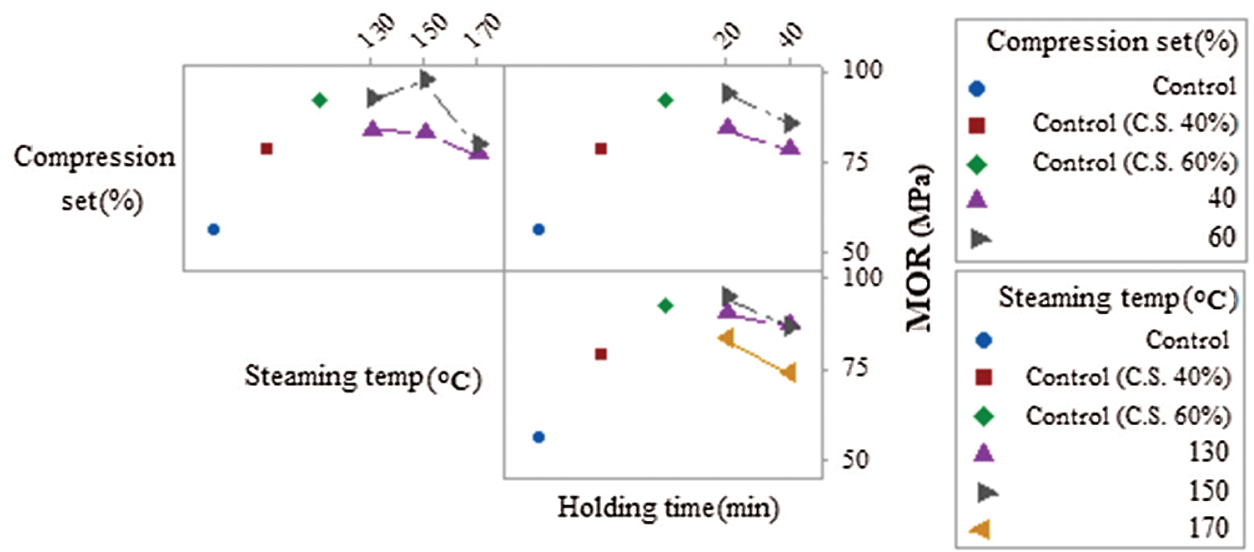

(a)
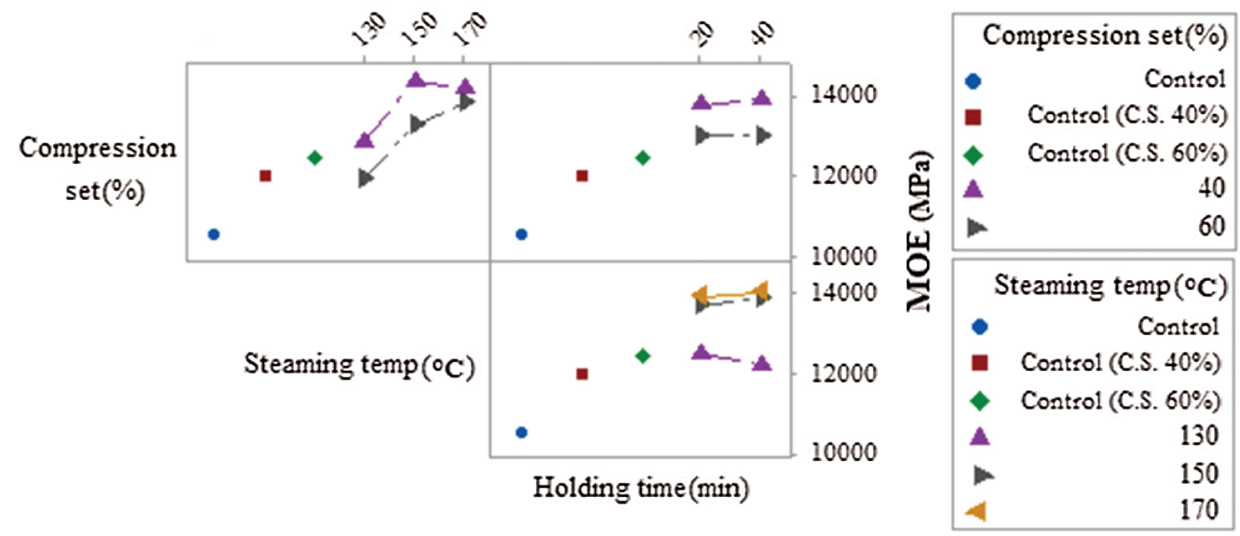

(b)

Figure 9: Effects of hygro-thermo-mechanical treatment parameters on MOR (a) and MOE (b) of glulam

The Modulus of elasticity (MOE) of glulam was increased due to temperature and holding time of hygrothermal treatment (Fig. 9b). However, the holding time had no significant effect on MOE but the steaming temperature was much more effective (Fig. 9b). Results also revealed that the MOE was increased due to the densification process as well as enhancement of compression set in control glulams (Fig. 9b). As shown in Fig. 9b, the hygrothermal treatment caused reduction of the MOE by increase of compression set. However, the MOE of glulams made from hygrothermal treated specimens with C.S. $40 \%$ and $60 \%$ was greater $15.5 \%$ and $4.8 \%$ than controls with the same compression set, respectively.

\subsubsection{Shear Strength of Glueline}

As indicated in Fig. 11, the densification process generally followed by improvement of the shear strength of glueline in controls. However, the increase of C.S. from 40 up to $60 \%$ caused reduction of this mechanical property in control specimens. Moreover, Fig. 12 shows structural of glueline in control glulams. It is clearly indicates that compression can create an integrated glueline and caused increment of the shear strength. Based on obtained results, the hygrothermal treatment temperature was the only significant negative parameter on shear strength of glueline. As shown, the least shear strength of glueline was determined in steaming temperature of $170^{\circ} \mathrm{C}$ (Fig. 11). The parameters holding time and compression set had a slight effect on shear strength of glueline in glulams made from hygro-thermomechanical treated specimens (Fig. 11). 

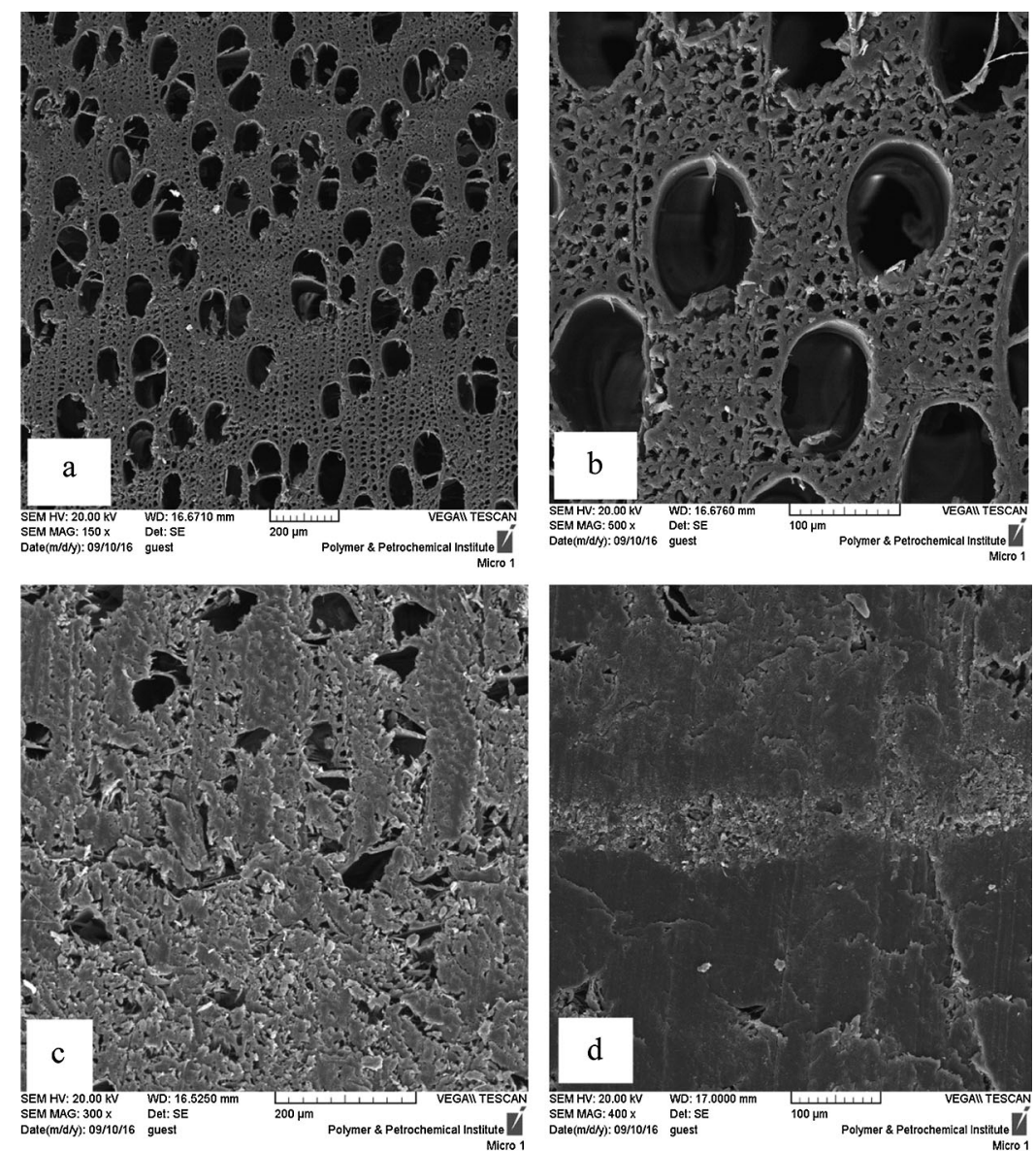

Figure 10: SEM photos of control (U) and densified wood (P2): a) control $\times 200 \mu \mathrm{m}, \mathrm{b}$ ) control specimen $\times$ $100 \mu \mathrm{m}, \mathrm{c})$ densified wood $\times 200 \mu \mathrm{m}$ d) densified $\operatorname{wood} \times 100 \mu \mathrm{m}$

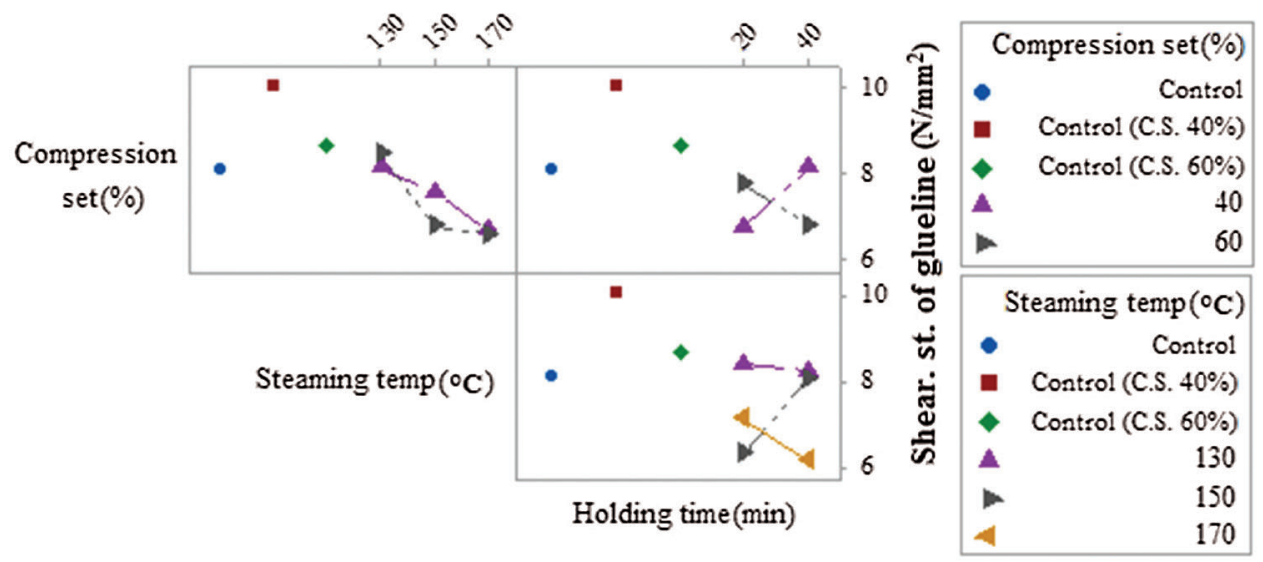

Figure 11: Effects of hygro-thermo-mechanical treatment parameters on shear strength of glueline 

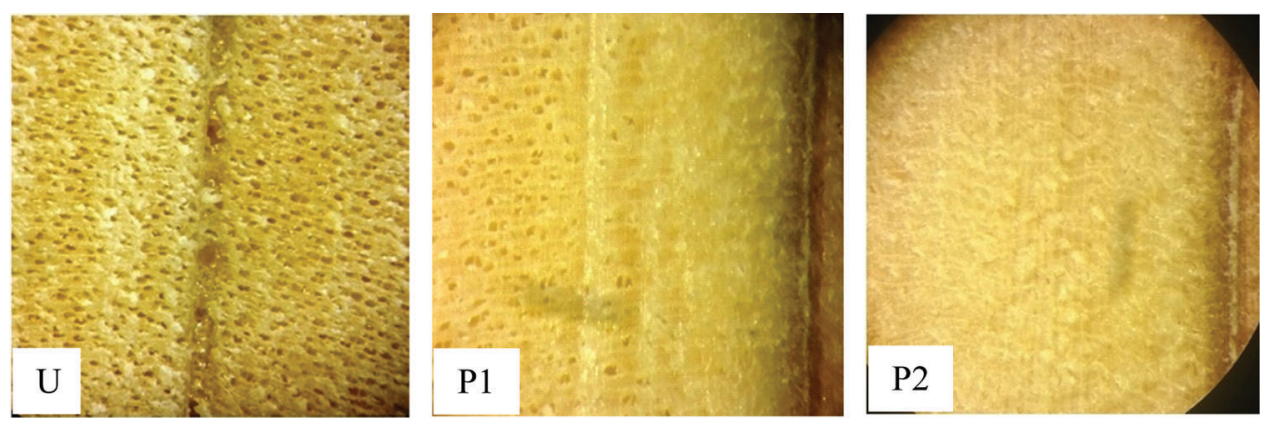

Figure 12: Bonding glueline of control glulam specimens: control specimen (left), control specimen with C.S. $40 \%$ (middle) and control specimen with C.S. $60 \%$ (right)

The results of shear strength of glueline also showed that all the failures occurred in the wood area (Fig. 13). In fact, hydrolysis of polysaccharides due to increasing the hygrothermal temperature causes shortening of the cellulose chain, in addition lignin and wood structure get brittle. Therefore compression causes small cracks in wood structure and as a result the shear strength of the wood is reduced, which ultimately leads to a decrease in the shear strength of the glueline.

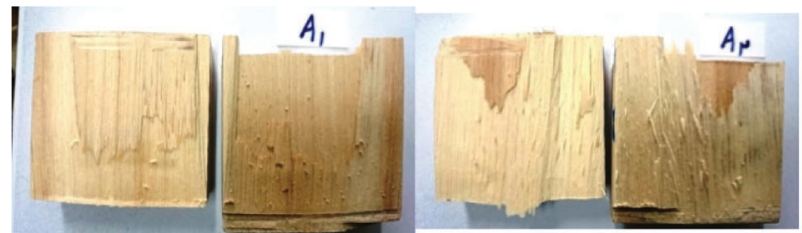

A1

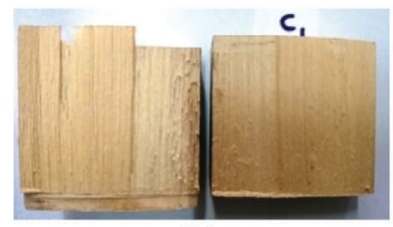

C1

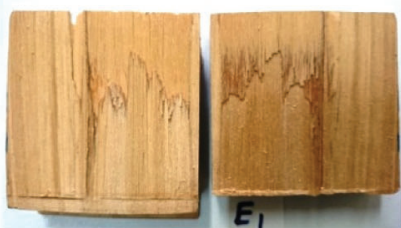

E1

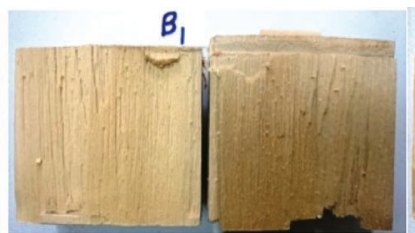

B1

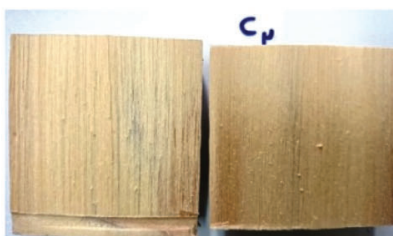

C2

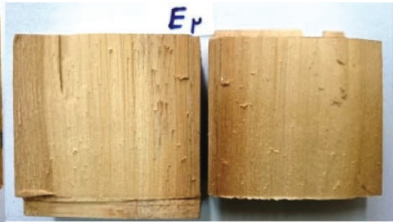

E2

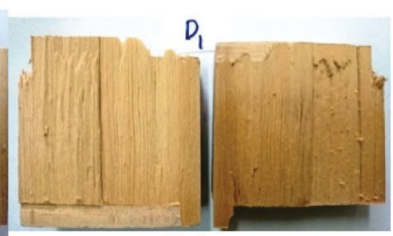

D1

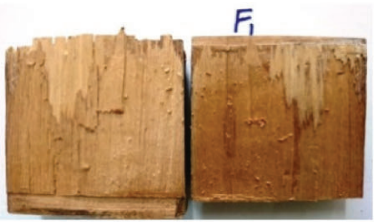

F1

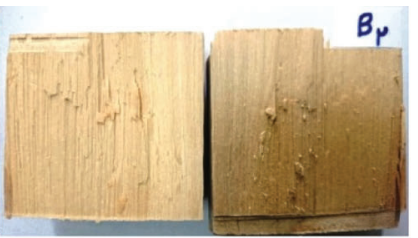

B2

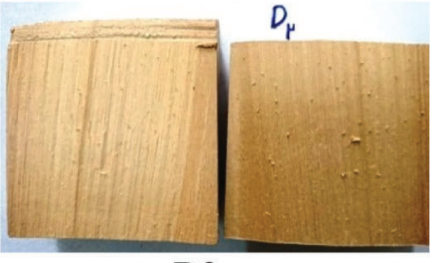

D2

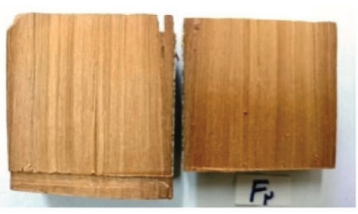

F2

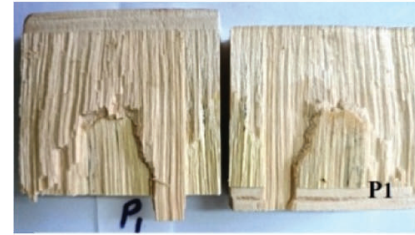

P1

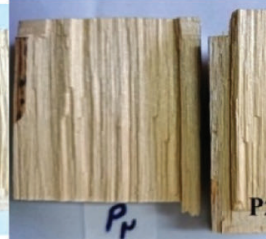

P2

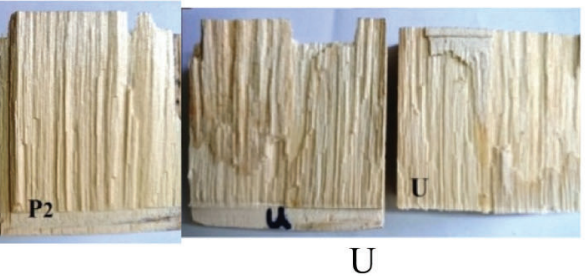

Figure 13: Wood failure of glulam specimens after glueline shear test (cods based on Tab. 1) 


\subsubsection{Compression Strength Parallel to Grain}

Results revealed, among the hygro-thermo-mechanical treatment parameters, the steaming temperature was the only significant factor on compression strength parallel to the grain. As the results indicates in Fig. 14 , the steaming temperature $150^{\circ} \mathrm{C}$ followed by the most compression strength parallel to the grain. Altogether, the densification process drastically increased compression strength parallel to the grain in controls (Fig. 14). However, the increase of C.S. up to $60 \%$ caused reduction of this mechanical feature in controls (Fig. 14). As shown, the least compression strength parallel to the grain was determined in control specimens without any treatment (Fig. 14), i.e., hygro-thermo-mechanical treatment totally caused improvement of compression strength parallel to the grain.
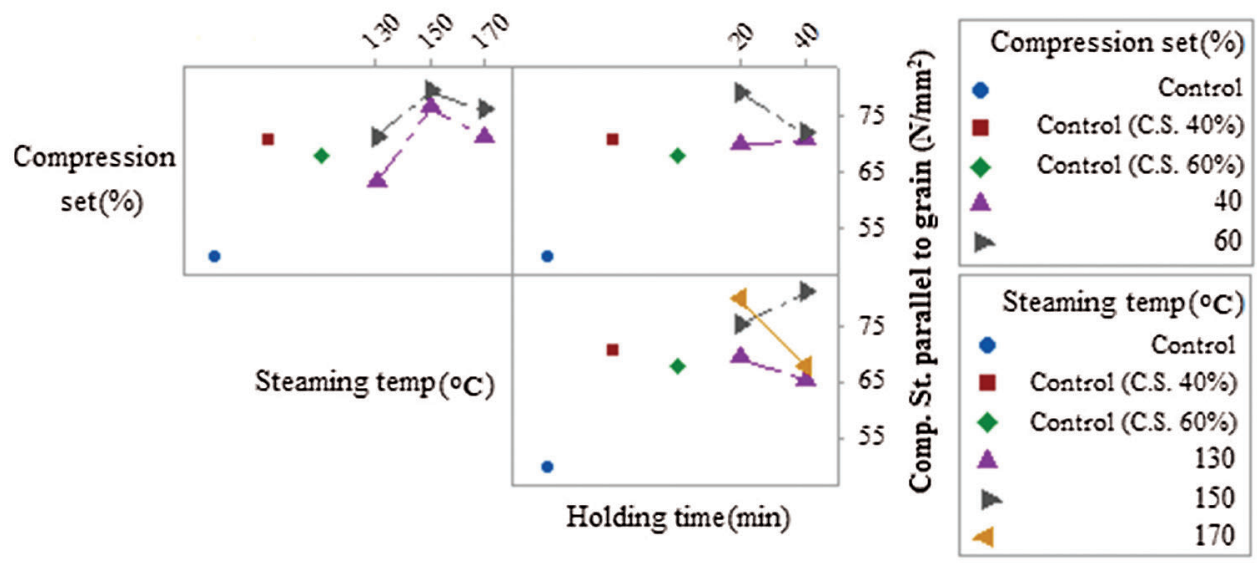

Figure 14: Effects of hygro-thermo-mechanical treatment parameters on compression strength parallel to grain

\section{Conclusions}

Based on the findings of this study the application of hygro-thermo-mechanical process resulted improvement of physical and mechanical properties of glulam. In this process, the compression increases density and hygrothermal treatment has a positive role in this field. All of applied process parameters have significant effect on water absorption; so that the steaming temperature and holding time drastically reduce water absorption but densification process increases this feature. The radial swelling decreases by increasing of hygrothermal parameters (steaming temperature and holding time); while compression process increases it. Moreover, all parameters of hygro-thermo-mechanical process decrease tangential swelling. Dimensional stability of specimens improves due to the hygrothermal treatment of this process.

The delamination of specimens increase by densification process, while hygrothermal treatment parameters decrease the delamination. Also, this modification method has completely positive effect on MOR and MOE. In this technique, compression process increases MOR while hygrothermal treatment caused reduction of MOR; and this is vice versa about MOE. The shear strength of glueline generally decreases by hygro-thermo-mechanical process. This method completely improves the compression strength parallel to the grain. The compression process increases this mechanical property, while hygrothermal treatment caused its reduction.

Acknowledgement: Authors would like to express their special thanks to Research Institute of Forests and Rangelands, Agricultural Research, Education and Extension Organization (AREEO) and Tarbiat Modares University for their scientific support in this research.

Funding Statement: The authors received no specific funding for this study. 
Conflicts of Interest: The authors declare that they have no conflicts of interest to report regarding the present study.

\section{References}

1. Yang, R., Li, H., Dauletbek, A., Ashraf, M., Lorenzo, R. et al. (2021). Effects of freeze-thaw cycles on physical and mechanical properties of glulam exposed to outdoor environment. Journal of Renewable Materials, 99(7), 1293-1307. DOI 10.32604/jrm.2021.015296.

2. Yang, T. H., Wang, S. Y., Tsai, M. J., Lin, C. Y. (2009). The charring depth and charring rate of glued laminated timber after a standard fire exposure test. Building and Environment, 44, 231-236. DOI 10.1016/j. buildenv.2008.02.010.

3. Issa, C. A., Kmeid, Z. (2005). Advanced wood engineering: Glulam beams. Construction and Building Materials, 19, 99-106. DOI 10.1016/j.conbuildmat.2004.05.013.

4. Yang, R., Hong, C., Zhang, X., Yuan, Q., Sun, Y. (2020). Experimental research on structural behaviors of glulam I-beam with a special-shaped section. Journal of Renewable Materials, 8(2), 113-132. DOI 10.32604/ jrm.2020.08190.

5. Okamoto, S., Akiyama, N., Araki, Y., Aoki, K., Inayama, M. (2021). Study on the strength of glued laminated timber beams with round holes: Difference in structural performance between homogeneous-grade and heterogeneous-grade timber. Journal of Wood Science, 67, 8. DOI 10.1186/s10086-021-01941-3.

6. LaCross, V. D., Manbeck, H. B., Witmer, R. W., Laman, J. A., Janowiak, J. J. (2000). Endurance of deck-to-deck connections in transverse hardwood glulam decks. Journal of Bridge Engineering, 5(1), 84-89. DOI 10.1061/ (ASCE)1084-0702(2000)5:1(84).

7. Smith, I., Foliente, G., Nguyen, M., Syme, M. (2005). Capacities of dowel-type fastener joints in Australian pine. Journal of Materials in Civil Engineering ASCE, 17(6), 664-675. DOI 10.1061/(ASCE)0899-1561(2005)17:6(664).

8. Stehn, L., Börjes, K. (2004). The influence of nail ductility on the load capacity of a glulam truss structure. Engineering Structures, 26(6), 809-816. DOI 10.1016/j.engstruct.2004.01.012.

9. Zahn, J. J., Rammer, D. R. (1995). Design of glued laminated timber columns. Journal of Structural Engineering ASCE, 121(12), 1789-1794. DOI 10.1061/(ASCE)0733-9445(1995)121:12(1789).

10. Hill, C. A. S. (2006). Wood modification: Chemical, thermal and other processes. John Wiley \& Sons, Ltd.

11. Kozakiewicz, P., Drożdżek, M., Laskowska, A., Grześkiewicz, M., Bytner, O. et al. (2019). Effects of thermal modification on the selected physical properties of sapwood and heartwood of black poplar (Populus nigra L.). BioResources, 14, 8391-8404.

12. Liu, S. (2008). A kinetic model on autocatalytic reactions in woody biomass hydrolysis. Journal of Biobased Materials and Bioenergy, 2, 135-147. DOI 10.1166/jbmb.2008.304.

13. Garrote, G., Domínguez, H., Parajó, J. C. (1999). Hydrothermal processing of lignocellulosic materials. Holz als Roh- und Werkstoff, 57, 191-202. DOI 10.1007/s001070050039.

14. Ramos, L. P. (2003). The chemistry involved in the steam pretreatment of lignocellulosic materials. Quimica Nova, 26, 863-871. DOI 10.1590/S0100-40422003000600015.

15. Assor, C., Placet, V., Chabbert, B., Habrant, A., Lapierre, C. et al. (2009). Concomitant changes in viscoelasticity properties and amorphous polymers during the hydrothermal treatment of hardwood and softwood. Journal of Agricultural and Food Chemistry, 57, 6830-6837. DOI 10.1021/jf901373s.

16. Biswas, A. K., Yang, W., Blasiak, W. (2011). Steam pretreatment of salix to upgrade biomass fuel for wood pellet production. Fuel Processing Technology, 92, 1711-1717. DOI 10.1016/j.fuproc.2011.04.017.

17. Lam, P. S., Sokhansanj, S., Bi, X., Lim, C. J., Melin, S. (2011). Energy input and quality of pellets made from steam exploded douglas Fir (Pseudotsuga menziesii). Energy \& Fuels, 25, 1521-1528. DOI 10.1021/ef101683s.

18. Militz, H. (2002). Thermal treatment of wood. european processes and their background. IRG/WP 02-40241. 33rd Annual Meeting, 4, 1-17. 
19. Militz, H. (2008). Process and properties of thermally modified wood manufactured in Europe. ACS Symposium Series, vol. 982, pp. 372-388. DOI 10.1021/bk-2008-0982.ch022.

20. González-Peña, M. M., Breese, M. C., Hill, C. A. S. (2004). Hygroscopicity in heat treated wood: Effect of extractives. 1st International Conference on Environmentally-Compatible Forest Products, pp. 105-109. Fernando Pessoa University, Oporto, Portugal.

21. Krause, A., Hof, C., Militz, H. (2004). Novel wood modification processes for window and cladding products. 35th Annual Meeting, International Research Group on Wood Protection.

22. Obataya, E., Tomita, B. (2002). Hygroscopicity of heat-treated wood II, reversible and irreversible reductions in the hygroscopicity of wood Due to heating. Mokuzai Gakkaishi, 48(4), 288-295.

23. Militz, H., Tjeerdsma, B. (2001). Heat treatment of wood by the PLATO process. In: Rapp, A. O. (Editor), Review on Heat Treatments of Wood. COST ACTION E22: Environmental Optimisation of Wood Protection, pp. 27-38.

24. Huang, C. X., Lin, W. Q., Lai, C. H., Li, X., Jin, Y. C. et al. (2019). Coupling the post-extraction process to remove residual lignin and alter the recalcitrant structures for improving the enzymatic digestibility of acid pretreated bamboo residues. Bioresource Technology, 285, 121355, DOI 10.1016/j.biortech.2019.121355.

25. Welzbacher, C. R., Wehsener, J., Rapp, A. O., Haller, P. (2008). Thermo-mechanical densification combined with thermal modification of Norway spruce (Picea abies karst) in industrial scale-dimensional stability and durability aspects. Holz als Roh- und Werkstoff, (66), 39-49. DOI 10.1007/s00107-007-0198-0.

26. González-Peña, M. M., Hale, M. D. C. (2007). The relationship between mechanical performance and chemical changes in thermally modified wood. Proceedings 3rd European Conference on Wood Modification, pp. 169-172.

27. Sundqvist, B., Karlsson, O., Westermark, U. (2006). Determination of formic-acid and acetic acid concentrations formed during hydrothermal treatment of birch wood and its relation to colour, strength and hardness. Wood Science and Technology, 40, 549-561. DOI 10.1007/s00226-006-0071-z.

28. Bytner, O., Laskowska, A., Drożdżek, M., Kozakiewicz, P., Zawadzki, J. (2021). Evaluation of the dimensional stability of black poplar wood modified thermally in nitrogen atmosphere. Materials, 14, 1491. DOI 10.3390/ ma14061491.

29. Dwianto, W., Inoue, M., Tanaka, F., Norimoto, M. (1998). The permanent fixation of compressive deformation in wood by heat treatment. Proceeding of 3rd Pacific Rim Bio-Based Composite Symposium, pp. 231-239.

30. Gong, M., Lamason, C., Li, L. (2010). Interactive effect of surface densification and post-heat- treatment on aspen wood. Journal of Materials Processing Technology, 210, 293-296. DOI 10.1016/j.jmatprotec.2009.09.013.

31. Blomberg, J. (2005). Elastic strain at semi-isostatic compression of Scots pine (Pinussylvestris). Journal of Wood Science, 51, 401-404.

32. Kutnar, A., Kamke, F., Sernek, M. (2008). Density and morphology of viscoelastic thermal compressed (VTC) wood. Wood Science and Technology. DOI 10.1007/s00226-008-0198-1.

33. Metsa-Kortelainen, S., Antikainen, T., Viitaniemi, P. (2006). The water absorption of sapwood and heartwood of Scots pine and Norway spruce heat-treated at $170^{\circ} \mathrm{C}, 190^{\circ} \mathrm{C}, 210^{\circ} \mathrm{C}$ and $230^{\circ} \mathrm{C}$. Holz als Roh- und Werkstoff, 64 (3), 192-197.

34. Boonstra, M. J., Blomberg, J. (2007). Semi-isostatic densification of heat-treated radiate pine. Wood Science and Technology, 41, 607-617.

35. Esteves, B., Marques, A. V., Domingos, I., Pereira, H. (2007). Influence of steam on the properties of pine (Pinus pinaster) and eucalypt (Eucalyptus globulus) wood. Wood Science and Technology, 41, 193-207.

36. Hillis, W. E. (1984). High temperature and chemical effects on wood stability. Part 1-General considerations. Wood Science and Technology, 18, 281-293.

37. Hsu, W. E., Schwald, W., Schwald, J., Shields, J. A. (1988). Chemical and physical changes required for producing dimensionally stable wood-based composites. Wood Science and Technology, 22, 281-289.

38. Inoue, M., Norimoto, M., Tanahashi, M., Rowell, M. R. (1993). Steam or heat fixation of compressed wood. Wood and Fiber Science, 25(3), 224-235.

39. Dwianto, W., Morooka, T., Norimoto, M., Kitajima, T. (1999). Stress relaxation of Sugi (Cryptomeria japonica D. don) wood in radial compression under high temperature steam. Holzforschung, 53, 541-546. 
40. Fukuta, S., Takasu, Y., Sasaki, Y., Hirashima, Y. (2007). Compressive deformation process of Japanese cedar (Cryptomeria japonica). Wood and Fiber Science, 39, 548-555.

41. Ito, Y., Tanahashi, M., Shigematsu, M., Shinoda, Y., Ohta, C. (1998). Compressive-molding of wood by highpressure steam-treatment: Part 1, development of compressively molded squares from thinnings. Holzforschung, 52, 211-216. DOI 10.1515/hfsg.1998.52.2.211.

42. Mohebby, B., Sharifnia-Dizboni, H., Kazemi-Najafi, S. (2009). Combined hydro-thermo-mechanical modification (CHTM) as an innovation in mechanical wood modification. Proceeding of 4th European Conference on Wood Modification (ECWM4), pp. 353-360.

43. Navi, P., Girardet, F. (2000). Effects of thermo-hydro-mechanical treatment on the structure and properties of wood. Holzforschung, 54, 287-293. DOI 10.1515/HF.2000.048.

44. Navi, P., Heger, F. (2004). Combined densification and thermo-hydro-mechanical processing of wood. MRS Bulletin, 29, 332-336. DOI 10.1557/mrs2004.100.

45. Tjeerdsma, B. F., Militz, H. (2005). Chemical changes in hydrothermal treated wood. FTIR analysis of combined hydro thermal and Dry heat-treated wood. Holz als Roh- und Werkstoff, 63(2), 102-111. DOI 10.1007/s00107-004-0532-8.

46. Welzbacher, C. R., Wehsener, J., Rapp, A. O., Haller, P. (2008). Thermo-mechanical densification combined with thermal modification of Norway spruce (Piceaabies karst) in industrial scale-dimensional stability and durability aspects. Holz als Roh- und Werkstoff, 66, 39-49. DOI 10.1007/s00107-007-0198-0.

47. Hakkou, M., Petrissans, M., Ceradine, P., Zoulalian, A. (2006). Investigation of the reasons for fungal durability of heat treated beech wood. Polymer Degradation and Stability, 91(2), 393-397. DOI 10.1016/j. polymdegradstab.2005.04.042.

48. Khademi, L., Mohebby, B. (2011). Bioresistance of poplar wood compressed by combined hydro-thermomechanical wood modification (CHTM): Soft-rot and brown-rot. International Biodeterioration \& Biodegradation, 65, 866-870. DOI 10.1016/j.ibiod.2011.03.011.

49. Dwainto, W., Inoue, M., Norimoto, M. (1997). Fixation of deformation of wood by heat treatment. Makuzai Gakkaishi, 43(4), 303-309.

50. Ohnesorge, D., Richter, K., Becker, G. (2010). Influence of wood properties and bonding parameters on bond durability of european beech glulams. Annals of Forest Science, 67(6), 601-611. DOI 10.1051/forest/2010002.

51. Alvira, P., Tomás-Pejó, E., Ballesteros, M., Negro, M. J. (2010). Pretreatment technologies for an efficient bioethanol production process based on enzymatic hydrolysis: A review. Bioresource Technology, 101, 48514861. DOI 10.1016/j.biortech.2009.11.093. 